\title{
The septoria leaf blotch of wheat in Central Kazakhstan: prognosis, evaluation and monitoring with remotely sensed data
}

\author{
Dmitry V. Malakhov \\ Joint Stock Company “National Center for Space Research and Technology”, Almaty, 050010, Kazakhstan. d_malakhov_73@mail.ru
}

*Corresponding Author (https://orcid.org/0000-0002-7844-6569)

\begin{abstract}
Fungal diseases represent a widely spread natural phenomenon affecting many wild and domesticated plants. In nature, all plant species forms plant communities of a mixed character, and the spatial pattern of dominant species is usually irregular and spotted. Some species are impregnable to a certain infection, which provides a kind of natural barrier to the infection spread within the natural community. Under the agricultural environment, when the single plant species may occupy a huge area, the species-specific parasite takes a great advantage to develop focal outbreaks and fast spreading of the infection within the area. The concentration of vulnerable plants and the absence of natural barriers within the agricultural areas provoke outbreaks of fungal diseases that may have highly harmful consequences and result in significant yield losses. One of the purposes of the satellite optical data is an operative, cost-effective diagnostic and, in combination with climatic datasets and crop rotation information, a prognosis of fungal disease appearance and severity. This paper describes the system of prognostic and monitoring measures to control the fungal diseases of wheat in Central Kazakhstan with particular attention to septoria leaf blotch. The prognostic procedure provides a map of the probability of septoria leaf blotch appearance. The prognosis considers the combination of three main variables: the model of ecological niche for Septoria, the presence of wheat residue, and the Vegetation Condition Index counted for the late spring (May) of the current year. The novel spectral-based approach, introduced in this paper, is the core component of monitoring activity. The $S L B S$-equation appears to have high sensitivity to septoria leaf blotch severity at middle to late (stages 8-11, accordingly Feekes growth stages) periods of wheat development. Several other spectral indices (RETA, VSDI, vegetation indices) may help provide information on the spatial unevenness of wheat crops that may indicate the presence of fungal infection.
\end{abstract}

Keywords: fungal wheat diseases, remote sensing, monitoring, prognosis

Received: April 16 ${ }^{\text {th }}, 2021 /$ Accepted: May 19 $9^{\text {th }}, 2021 /$ Online: June $23^{\text {rd }}, 2021$

\section{Introduction}

At the end of XX century, wheat (Triticum aestivum L.) was grown on about 239 million hectares, $8 \%$ of which were in western Europe, $16 \%$ in North America, $4 \%$ in eastern Europe, $11 \%$ in the Russian Federation countries, and 38\% in Asia (Verreet et al., 2000). Annually, on average, about 13.0 million tons of grain are produced in Kazakhstan. The average grain yield is 1.1 tons per hectare (Babkenova et al., 2020). Septoria leaf blotch is one of the most destructive fungal pathogen of wheat in all wheat-producing areas (Toropova et al., 2016). Pathogen leads to the decrease of chlorophyll content in leaf tissues. The 
destruction of chloroplasts and the shrink of the assimilation area of the leaf lead to the reduction of photosynthesis activity and the diminution of respiratory activity (Melkumov, Brazhnikova, 2018). Yield losses occur mainly as a result of grain content decrease within the single ear and decrease of grain weight in general (Babkenova et al., 2020). Septoria tritici and Stagonospora (Septoria) nodorum cause significant crop loss and severely reduce grain quality. Annual yield losses may reach 10-15\% in cases of moderate development of the disease (Karjalainen, Karjalainen, 1990) and up to 40-50 \% during epiphytoties (Toropova et al., 2016; Tadesse et al., 2020).

As many as ten fungal pathogens causing the septoria blotch in wheat are recently known. Often the single wheat plant may possess several infections at the same time (Diseases..., 1989). The main sources of the infection are infected leaves of the living plant, wheat residue, and infected seeds. The most common pathogens are Septoria tritici, Septoria graminum, and Septoria nodorum (Koyshibayev, 2002; Peresypkin, 1969). A moist period of 15 hours was found to be a minimum condition for infection, whereas 35 hours of moisture followed by 2 days of high humidity favored heavy infection (Hess, Shaner, 1987). The greatest disease severities resulted from the combination of long moist periods and high temperature (Hess, Shaner, 1987). However, it was shown that humidity and temperature do not appear to be limiting factors in a susceptible cultivar, as the Septoria can tolerate prolonged, and repeated interruptions to humid periods and still infect efficiently (Shaw, Royle, 1993). Maximum of the disease development may be observed at the stages $10^{\text {th }}$ and $11^{\text {th }}$ (by Cooke et al., 2006) of the plant development, i.e. at flowering and grain ripening, at the ambient air temperature of $14-22^{\circ} \mathrm{C}$ and relative air humidity of $90 \%$ or above. All above-ground parts of the plant may be infected, depending on the pathogen and disease severity. The disease symptoms usually look like elongated spots of a different color (from white to brown) on leaves with dark outlines and dark dots scattered throughout the spot area. Dark dots represent pycnidia - the organ where the pycnospores come from. Severely infected leaves become completely dry, grains lose weight, or they may become undeveloped. Septoria spreads by pycnospores during the vegetation season, moist weather intensifies the release of pycnospores from pycnidia. Pathogen winters in a form of either mycelium or pycnidia at wheat residuals on the top of the soil. Septoria nodorum winters in the form of mycelium within infected seeds as well. As a rule, there are several generations of pycnidia during the vegetation season. The pathogen may spread via water drops as well as by winds or insects.

Data on the fungal diseases were collected by JSC "NCSRT" for many years (2004-2017) in Aqmola, Kostanay, and North-Kazakhstan Districts as georeferenced points of disease occurrence. Data acquired during 2004-2017 were used to develop the Species Distribution Model for the disease's pathogen (Malakhov et al., 2017). Last two years (2019-2020), the data collection was redesigned into the form of the registration of disease symptoms within selected fields in Aqmola District. In the period mentioned, the experimental polygon within Aqmola District was selected to provide a further collection of experimental data at wheat fields of the selected polygon.

\section{Material and methods}

\subsection{Study area}

The study area is represented with fields of JCS "Novokubanskoye" located in Shortandy Region of Aqmola District (Figure 1). The study area encompasses a series of fields to cultivate different crops, like linen, barley, lentil etc., while wheat is a major type of crop. Geographically the study area belongs to the dry continental steppe characterized by warm summer and cold winter ( $D f b$ zone by Köppen-Geiger, after Kottek et al., 2006) with annual precipitation of $300-310 \mathrm{~mm}$. Calcic chernozem is the main soil type of the area. 


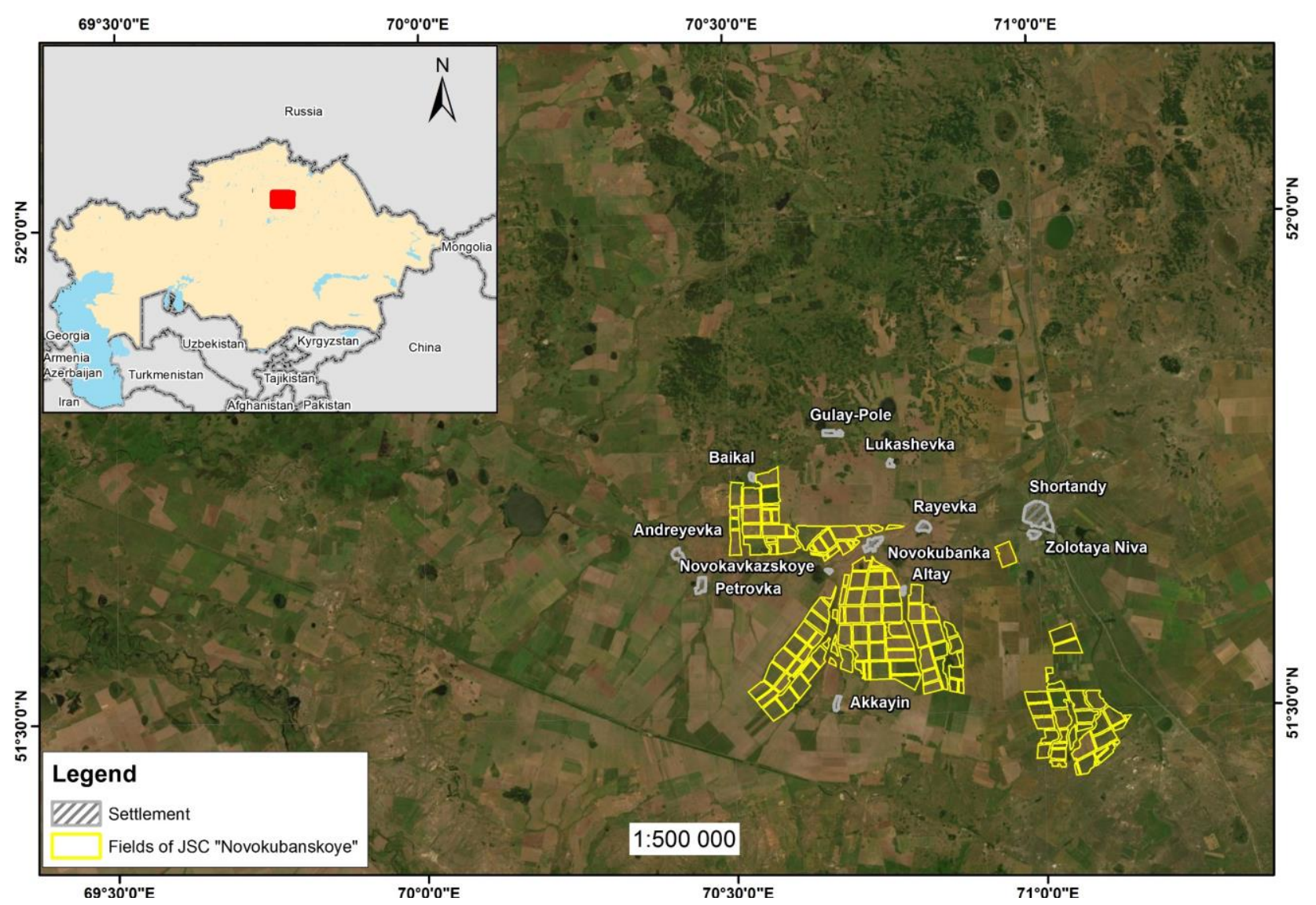

Figure 1. Study area. JSC "Novokubanskoye”, Aqmola District, Republic of Kazakhstan.

\subsection{Ground data and measurements}

Three fields were chosen in the year 2019 to provide field measurements depending on septoria leaf blotch severity. Disease severity can be defined as the area of a sampling unit (plant surface) affected by the disease, expressed as a percentage or proportion of the total area. However, the disadvantage of visual estimates is that they are prone to subjectivity (El Jarroudi et al., 2015). Since the top three leaves are known to make the main contribution to grain yield (Shaw, Royle 1989) we used a simplified scheme to define the severity of septoria leaf blotch, as described below:

1. Weak severity or initial stage of infection-only lower leaves are affected at stages 9-11 in most observed plants;

2. Moderate severity-lower and middle leaves are infected with sporadic spots at the flag leaf at stages 9-11 in most observed plants;

3. Strong severity-infection spreads over the flag leaf at stages 9-11 within the entire field of wheat.

The temperature of the crops and GreenSeeker's NDVI were measured and GPS-registered within the 1kilometer long route with a period of 40-50 meters (Figure 2) at each sampled field. The temperature of crops and bare soil was measured with an infrared remote thermometer. The temperature of crops markedly differs between infected and intact plants, and this difference was documented by other studies (Wang et al., 2014). Despite thermal information perspectives, however, this paper is focused on non-thermal indices, since firstly, - the thermal information on the Earth surface is limited with a few satellite sensors, and secondly - the distribution of thermal fields might be one of the additional criteria to reveal disease symptoms rather than the main diagnostic parameter. It is obvious, the temperature of plants is influenced by many factors, like the water 
content and evapotranspiration intensity, the air humidity, the soil moisture, the rainfall that occurred short before the satellite image was taken, etc., so the high temperature of crops itself might not be a sufficient indicator of the infection.

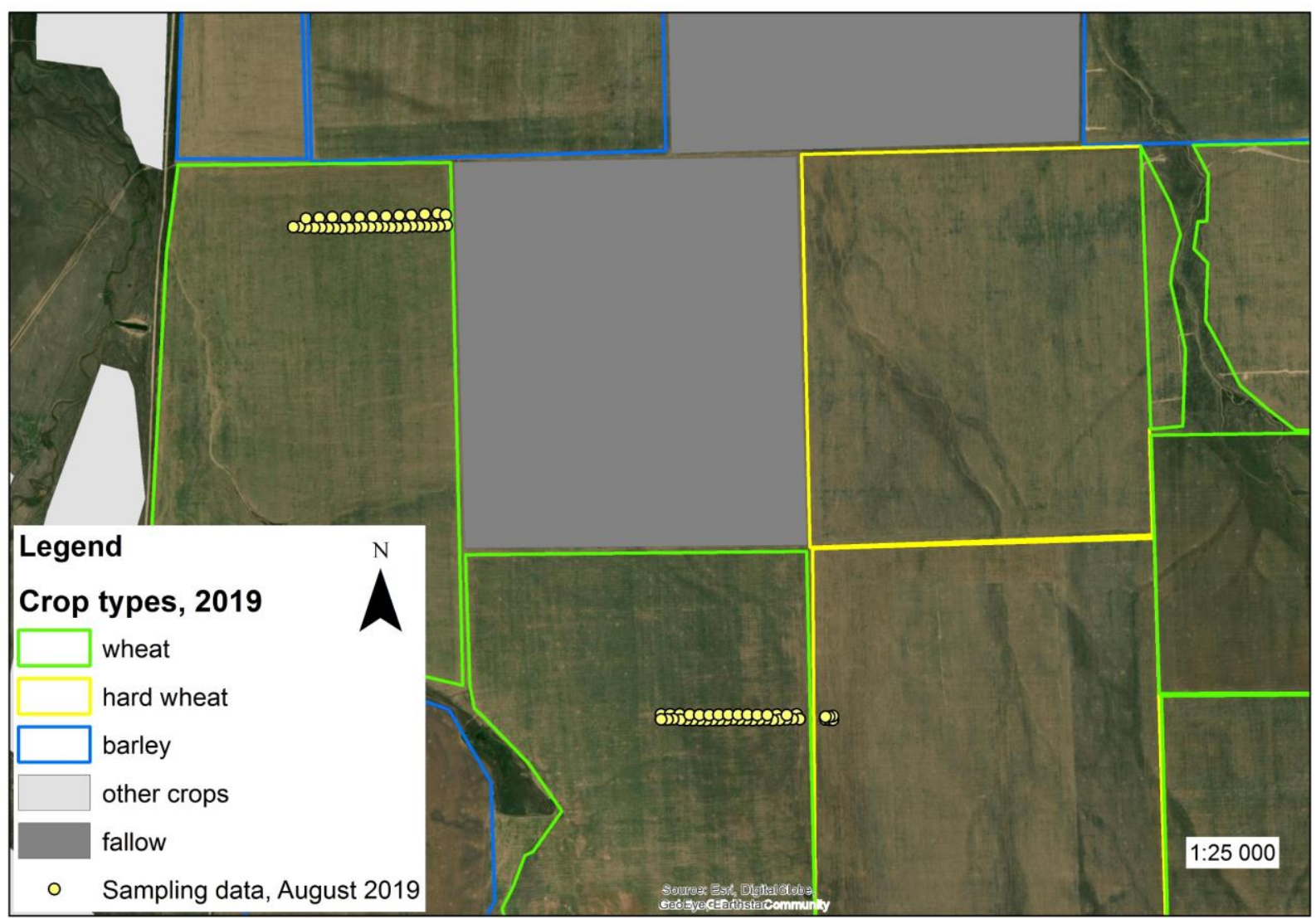

Figure 2. Example of field sampling design in 2019. Dots indicate the sampling and measuring points.

The Trimble GreenSeeker handheld crop sensor emits brief bursts of red and infrared light and then measures the amount of each type of light that is reflected back from the plant. The sensor displays the measured value in terms of an NDVI reading (ranging from 0.00 to 0.99 ) on its LCD display screen. The strength of the detected light is a direct indicator of the crop's health; the higher the reading, the healthier the plant. The sensor data were obtained for each sampling point within all mentioned fields and compared to satellite indices, and the ground measured septoria blotch severity as well.

Crop rotation schemes for 2019 and 2020 were acquired from N. Tsiunel, the agronomist of JSC "Novokubanskoye" to develop a digital map of crops and exclude non-wheat fields from the further analysis of satellite data.

Satellite data, synchronous to field observation of 2019, were acquired from Earth Explorer (https://earthexplorer.usgs.gov). Downloaded satellite imagery was atmospherically corrected, radiometrically calibrated, and used to calculate a series of spectral indices (Table 1).

Vegetation indices were used to estimate the correlations between current septoria leaf blotch severity in the field and indices' values calculated from synchronous satellite data. A tested series of indices comprises simple and advanced vegetation indices and non-vegetation indices sensitive to certain biophysical parameters of green vegetation that do not directly concern the chlorophyll content.

Table 1. List of spectral indices used to correlate ground and satellite data. 
Basic indices

Normalized difference vegetation index, NDVI

Enhanced vegetation index, EVI

\section{Expression}

$N D V I=\frac{\text { nir }- \text { red }}{\text { nir }+ \text { red }}$
Reference

Rouse et al., 1973

$$
E V I=\left(\frac{\text { nir }- \text { red }}{\text { nir }+6 * \text { red }-7.5 * \text { blue }+1}\right) * 2.5
$$

Huete et al. 2002

Yang et al., 2008.

\begin{tabular}{|c|c|c|}
\hline $\begin{array}{l}\text { Renormalized } \quad \text { Difference } \\
\text { Vegetation Index, RDVI }\end{array}$ & $R D V I=\frac{\text { nir }- \text { red }}{\sqrt{\text { nir }+ \text { red }}}$ & $\begin{array}{l}\text { Roujean, Breon, } \\
1995\end{array}$ \\
\hline
\end{tabular}

\begin{tabular}{|c|c|c|}
\hline $\begin{array}{l}\text { Atmospherically } \quad \text { Resistant } \\
\text { Vegetation Index, ARVI }\end{array}$ & $A R V I=\frac{(\text { nir }- \text { red })-2 *(\text { red }- \text { blue })}{(\text { nir }+ \text { red })-2 *(\text { red }- \text { blue })}$ & $\begin{array}{l}\text { Kaufman, Tanre, } \\
1992\end{array}$ \\
\hline PanNDVI & PanNDVI $=\frac{\text { nir }-(\text { blue }+ \text { green }+ \text { red })}{\text { nir }+(\text { blue }+ \text { green }+ \text { red })}$ & Wang et al., 2007 \\
\hline $\begin{array}{l}\text { Normalized Difference } \text { Water } \\
\text { Index, NDMI }\end{array}$ & $N D M I=\frac{n i r-s w i r_{1}}{n i r+s w i r_{1}}$ & Gao, 1995 \\
\hline $\begin{array}{l}\text { Visible Atmospherically } \\
\text { Resistant Index, VARI }\end{array}$ & $V A R I=\frac{\text { green }- \text { red }}{(\text { green }+ \text { red }- \text { blue })}$ & $\begin{array}{l}\text { Gitelson et al., } \\
2002\end{array}$ \\
\hline $\begin{array}{l}\text { Septoria Leaf Blotch Severity, } \\
\text { SLBS }\end{array}$ & $S L B S=1.0713-8.987 *\left(\frac{\left(N I R^{2}-R E D\right) * 1.5}{\left(N I R^{2}+R E D\right)+0.5}\right)$ & This paper \\
\hline
\end{tabular}

Supplemental indices

\section{Expression}

\section{Reference}

Visible and Shortwave Infrared Drought Index, VSDI

$$
V S D I=1-\left(\frac{\text { swir }_{2}-\text { blue }}{\text { red }- \text { blue }}\right)
$$

Zhang et al., 2013

Selyaninov's hydrothermal
coefficient, SHC

$S H C=P_{c p_{05}} /\left(\operatorname{sumT}_{05} / 10\right)$

\begin{tabular}{|c|c|}
\hline Vegetation condition Index, VCI & $V C I=\frac{n d v i_{\mathrm{i}}-\mathrm{ndv \textrm {i } _ { \operatorname { m i n } }}}{n d v i_{\max }-n d v \mathrm{i}_{\min }}$ \\
\hline
\end{tabular}

Selyaninov, 1937

\begin{tabular}{lcc}
$\begin{array}{l}\text { Relative evapotranspiration } \\
\text { index, RETA }\end{array}$ & $R E T A=333.8-47.54 *\left(1.05+0.6 *\left(\frac{N I R-\left(S W I R_{1}-S W I R_{2}\right)}{N I R+\left(S W I R_{1}-S W I R_{2}\right)}\right)\right.$ & This paper \\
\hline Xanthophyll activity index, XA & $X A=\frac{\text { red }- \text { blue }}{\text { red }+ \text { blue }}$ & $\begin{array}{l}\text { Peñuelas et al., } \\
1994\end{array}$
\end{tabular}

Selected vegetation indices comprise simple NIR-RED based expressions (NDVI) and advanced expressions that include additional spectral bands (all visible bands - PanNDVI, VARI; blue band-EVI, ARVI; SWIR band - NDMI) to enhance the index sensitivity to healthy vegetation. Also, indices with additional coefficients minimizing the signal of open soil or atmospheric aerosols ( $E V I, M N L I)$ were studied. Depending on the wheat's cultivar, wheat may be planted with different densities from 120 to 240 plants per square meter. The variety of additional factors and further disturbance of crops due to microrelief, drought, pests and diseases, may lead to spotted distribution of plants within the single field, with the appearance of areas, where the signal 
of open soil may oversaturate the signal of chlorophyll. In such a case, simple NIR-RED based vegetation indices may lose sensitivity or informativeness and provide unexpected errors when interpreting the classification results. Some indices, like RETA, XA, VSDI, NDMI, and VARI, were studied to determine their informative potential for mapping possible crop problems that may or may not be directly related to disease severity. In the year 2020, the list of sensors was extended with Sentinel-2 data. Sentinel-2 sensor provides additional spectral bands, including Red Edge bands, very useful for vegetation monitoring purposes, centered at 701.4, 740.5, and $782.8 \mathrm{~nm}$. Satellite data used in the current paper are summarized in Table 2.

Table 2. List of satellite data for 2019-2020, used in current paper preparation.

\begin{tabular}{ccc}
\hline Sensor & Scene ID & Date \\
\hline Landsat-8 & LC08_L1TP_155024_20190801_20190801_01_RT & 1 August 2019 \\
\hline Landsat-8 & LC08_L1TP_155024_20200413_20200422_01_T1 April 2020 & 29 April 2020 \\
\hline Landsat-8 & LC08_L1TP_155024_20200429_20200429_01_RT & 8 June 2020 \\
\hline Landsat-8 & LC08_L1TP_155024_20200531_20200608_01_T1 & 25 June 2020 \\
\hline Landsat-8 & LC08_L1TP_156024_20200623_20200625_01_RT & 3 August 2020 \\
\hline Landsat-8 & LC08_L1TP_155024_20200803_20200803_01_RT & 11 July 2020 \\
\hline Sentinel-2 & L1C_T42UXC_A026386_20200711T063407 & 24 May 2020 \\
\hline Sentinel-2 & L1C_T42UXC_A016791_20200524T062321 & \\
\hline
\end{tabular}

\section{Results}

\subsection{Monitoring function}

Vegetation indices, calculated for the year 2019, demonstrate high correlations to both disease severity and GreenSeeker values (Table 3).

Table 3. Correlations of spectral indices and ground data.

\begin{tabular}{lcccc}
\hline Index & Correlation to GreenSeeker & p-value & Correlation to disease severity & p-value \\
\hline NDVI & 0.78 & 0.05 & -0.53 & 0.05 \\
\hline $\boldsymbol{E V I}$ & 0.79 & 0.05 & -0.49 & 0.05 \\
\hline $\boldsymbol{M N L I}$ & 0.79 & 0.05 & -0.52 & 0.05 \\
\hline $\boldsymbol{R D V I}$ & 0.78 & 0.05 & -0.5 & 0.05 \\
\hline $\boldsymbol{A R V I}$ & 0.79 & 0.05 & -0.51 & 0.05 \\
\hline $\boldsymbol{N D M I}$ & 0.77 & 0.05 & -0.5 & 0.05 \\
\hline Xantophyll Index & -0.78 & 0.05 & 0.52 & 0.05 \\
\hline VARI & 0.77 & 0.05 & -0.29 & 0.05 \\
\hline PanNDVI & 0.77 & 0.05 & -0.55 & 0.05 \\
\hline VSDI & 0.78 & 0.05 & -0.49 & 0.05
\end{tabular}

The septoria leaf blotch severity expectedly negatively correlates to vegetation indices since the less chlorophyll concentration remained due to disease, the higher the septoria leaf blotch severity is documented at infected plants. Apart from other reasons leading to a decrease in the chlorophyll content (drought damage, lack of fertilizers, etc.) the development of infections may lead to uneven distribution of vegetation indices' 
values within the field. Uneven scattering of values indicates the presence of abnormality of the crop development and, regardless of the reason of unevenness, represents the hot spot to draw the farmer's attention. During the field sampling and satellite data processing, the triple cross-check of ground and satellite measurements has been performed: 1) the correlation of GreenSeeker data and satellite spectral indices; 2) the correlation of GreenSeeker measurements and septoria leaf blotch severity, and 3) the correlation of satellite spectral indices and septoria leaf blotch severity.

Of the indices studied, Modified Non-Linear Index (MNLI) demonstrated the highest correlations to both GreenSeeker and septoria leaf blotch severity, measured in the field (Figure 3).

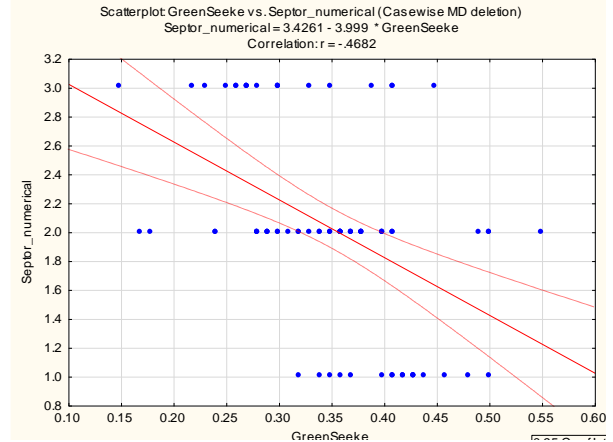

A.

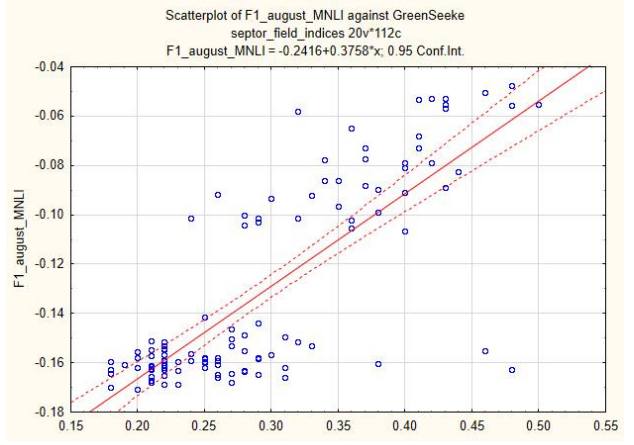

B.

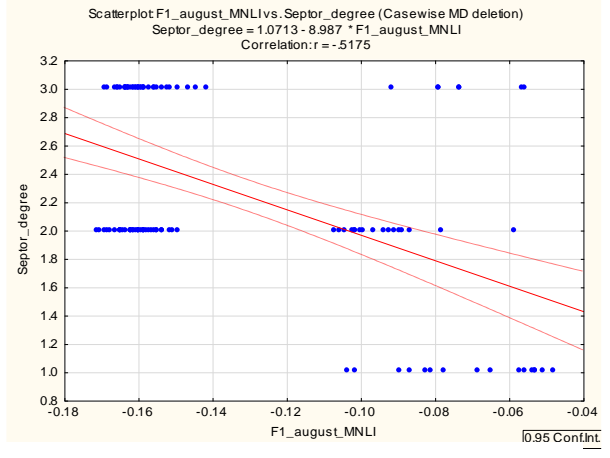

C.

Figure 3. Correlations of satellite and ground measurements, 1 August 2019. A - correlation of septoria leaf blotch severity (Y-axis) and GreenSeeker (X-axis); B - correlation of $M N L I$ (Y-axis) and GreenSeeker measurements (X-axis); $\mathrm{C}$ - correlation of septoria leaf blotch severity (Y-axis) and $M N L I$ values (X-axis).

The linear regression equation describing the Septoria Leaf Blotch Severity as a derivative of MNLI has the following form:

$$
S L B S=1.0713-8.987 *\left(\frac{\left(N I R^{2}-R E D\right) * 1.5}{\left(N I R^{2}+R E D\right)+0.5}\right)
$$

where NIR and RED are the corresponding bands of the satellite image.

The main purpose of the $S L B S$-equation is the early recognition of possible septoria leaf blotch by revealing the uneven distribution of $S L B S$ values within the field with special attention to hotspots of relatively high values. However, $S L B S$-equation may erroneously demonstrate high severity of septoria leaf blotch at late crops and at unevenly emerged crops, where the signal of the chlorophyll may be oversaturated by open soil signal.

The analysis of the consequent time series of satellite data reveals a low informative value of the $S L B S$ until mid-June i.e., before the earing stage (about 50 days after planting). The index becomes informative during the earing and flowering (stages 10-11, after Cooke et al., 2006) when the biomass of green wheat plants reaches its maximum. 
After the SLBS validation within selected fields by 2019 data, the expression has been applied to estimate the septoria blotch severity through the entire area of wheat fields of JSC "Novokubanskoye" for the year 2019 (Figure 4) and 2020 (Figure 5).

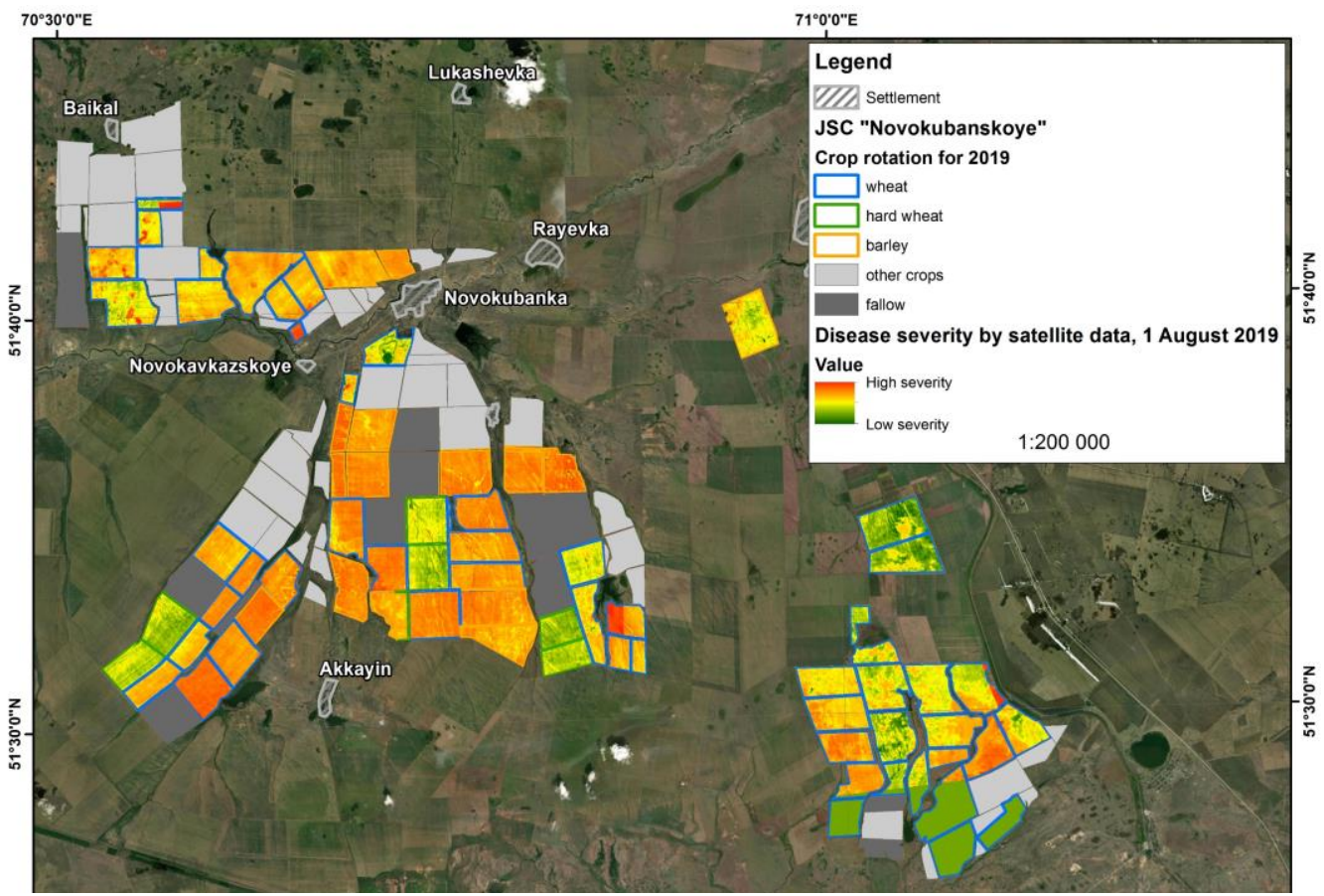

Figure 4. Septoria leaf blotch severity by satellite data, 1 August 2019.

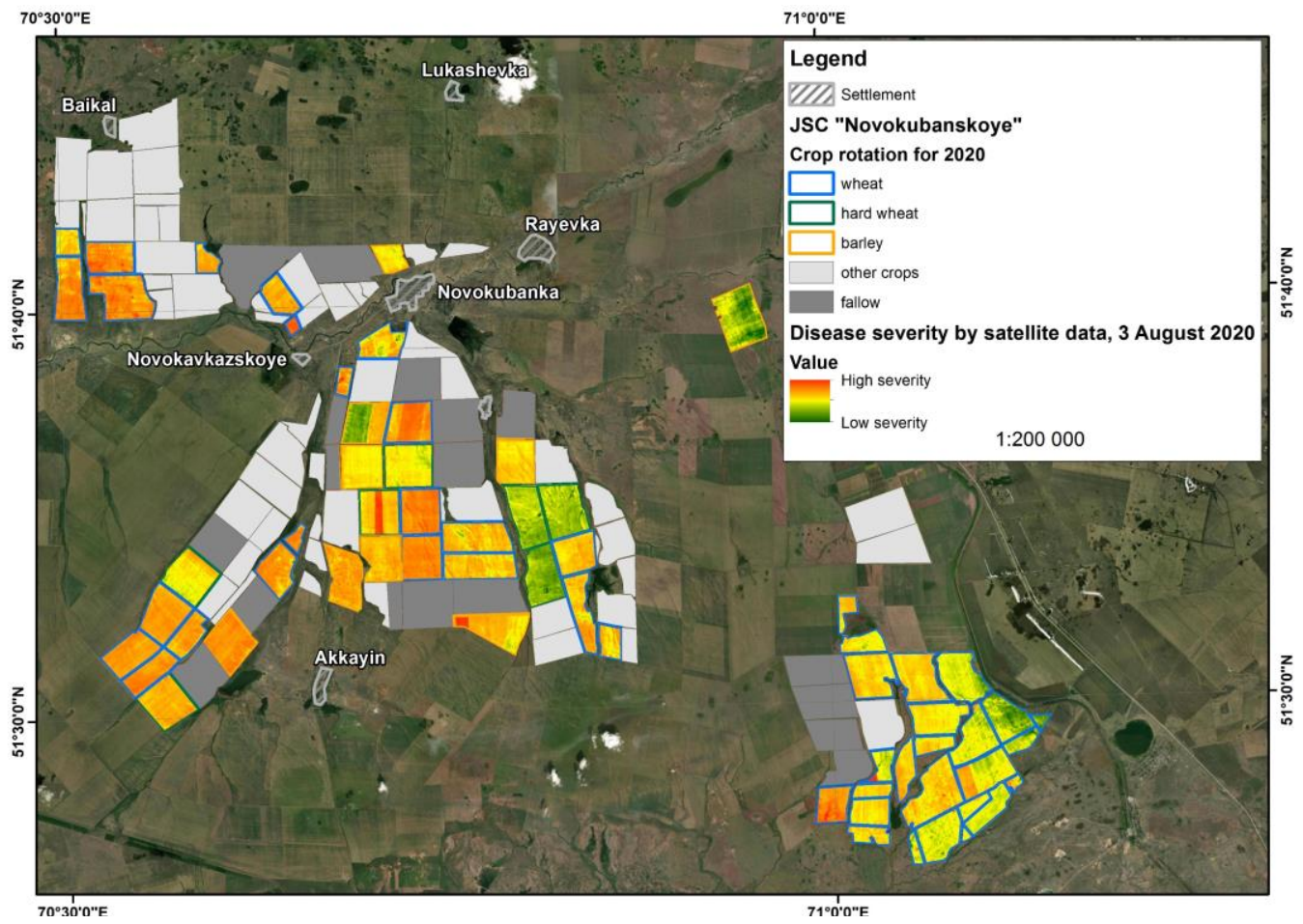

Figure 5. Septoria leaf blotch severity by satellite data, 3 August 2020. 
The validation of the $S L B S$ in 2020 has quite an indirect character as it was impossible to organize a field work at the appropriate period due to COVID-19 restrictions. It was possible to provide field observations in the second decade of August, when the major part of the wheat fields were completely dry and ripe, except of the $7^{\text {th }}$ Department's fields (see below in "Prognostic function" chapter). Thus, the validation of 2020 was primarily based at personal communications of JSC "Novokubanskoye" agronomist, who confirmed the extensive development of septoria leaf blotch in central and south-western parts of the area, as shown at Figure 5. Owners of JSC "Novokubanskoye" were pushed to hire an aircraft to provide the aerial fungicide treatment of the fields.

Additional evidence of possible disease appearance at the field may come from the estimation of the wheat's physiological conditions by remotely sensed data. Evapotranspiration is a physiological phenomenon associated with maintaining the optimal temperature by the plant due to the evaporation of water from the leaf surface. Exceeding the optimal temperatures leads to a slowdown in the biochemical processes in the plant cell, the destruction (denaturation) of protein molecules and cellular organelles, and, as a result, the wilting of the plant. The spatial distribution of relative evapotranspiration values provides the user with information about possible disease foci since one of the reasons for the decrease in the level of evapotranspiration is the damage to the leaf of plants by fungal diseases. The RETA index, introduced in this paper (Table 1), calculated from near-infrared and shortwave infrared bands of satellite sensors, may be used as auxiliary information when monitoring the condition of crops (Figure 6).

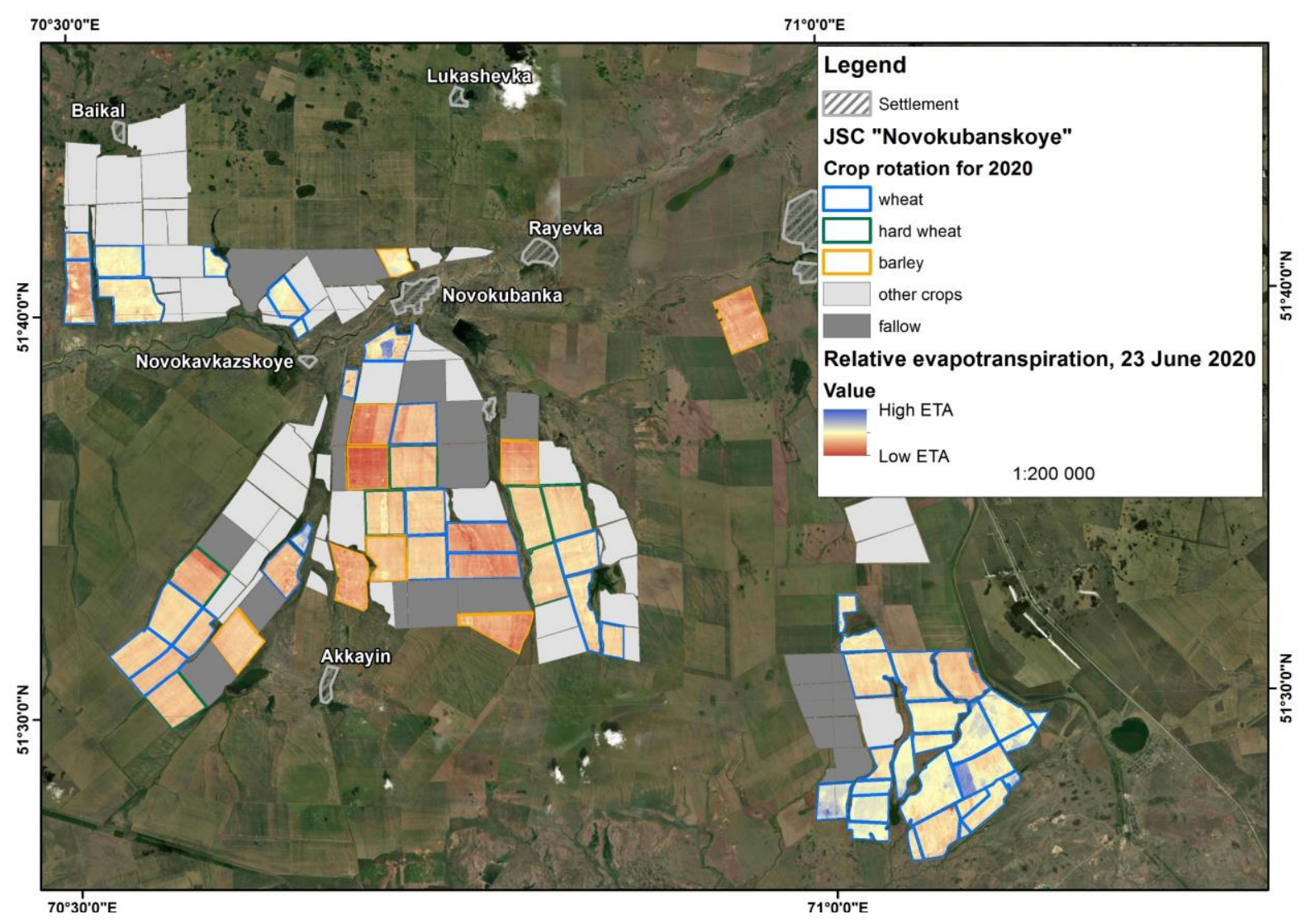

Figure 6. The heterogeneity of relative evapotranspiration, 23 June 2020.

The water content in green vegetation is another very important biophysical indicator. The series of studies explored the potential of using reflectance satellite data to estimate the vegetation water content at leaf, plant, and canopy scales (Jackson et al., 2004). Moisture reserves determine the ability of plants to maintain thermoregulation by evaporating moisture from the leaf over some time. The higher the relative water content, the longer the plant will be able to maintain the optimum temperature in drought conditions, which are common in Central Kazakhstan. The map of the vegetation water content distribution within the study area (Figure 7), 
calculated as VSDI (Table 1), may indicate possible foci of infection since a decrease in the moisture content in plants is directly related to the destruction of the cell structures of leaves and stems due to fungal diseases. Distribution of VSDI values, calculated in June, appears to be correlated to SLBS hot spots, revealed in Early August (compare Fig. 5 and Fig. 7). This similar appearance of the two algorithms is the subject of further study.

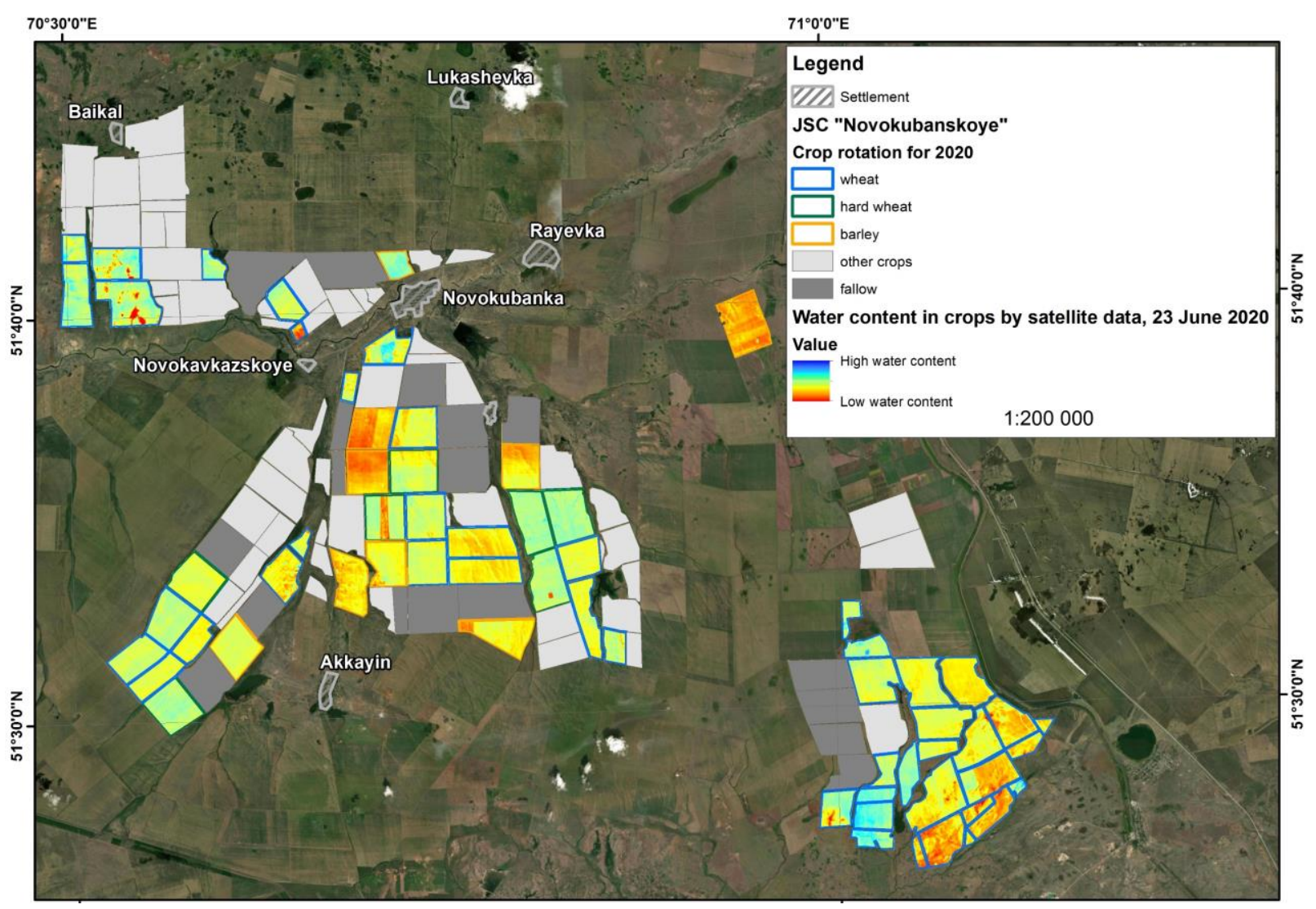

Figure 7. The heterogeneity of water content in green biomass, 23 June 2020.

\subsection{Prognostic function}

In the year 2020, the monitoring routine has been further enhanced with prognostic function. The simple prognostic scheme was developed basing on the use of three components. One component is static, and two others are dynamically changing each year. The static component is the probability of the septoria leaf blotch appearance derived from the Spatial Distribution Model (SDM), previously developed for the Aqmola District (Malakhov et al., 2017). One of the dynamic components is the value of VCI for the spring months (especially for May) in the monitoring area. The second dynamic component is the presence of wheat residue in the fields. Both dynamic components (or variables) are calculated from satellite data.

Accordingly to the SDM, most favorable areas for the development of the pathogen possess the following characteristics: a) maximum and mean temperatures of warmest season do not exceed $30{ }^{\circ} \mathrm{C}$; b) minimum temperature of the coldest month does not drop below $22{ }^{\circ} \mathrm{C}$; c) mean temperature of summer months is about $12-20{ }^{\circ} \mathrm{C}$; d) minimum temperature of winter months is not less than $(-20)-(-22){ }^{\circ} \mathrm{C}$; e) evapotranspiration in June, July and August varied between 120-160 mm; f) total precipitation of May is no less than 3-4 mm.

The hydrothermal conditions regulating the development of septoria leaf blotch are well studied (Koyshibayev, 2002). Intervals of Selyaninov's hydrothermal coefficient (SHC) optimal for septoria blotch development are well-established (Koyshibayev, 2002). However, the direct use of $S H C$, calculated from ground meteorological stations data, has strict spatial limitations related to the low density of meteorological stations in the region. 
Data on $S H C$, acquired from few stations, should be interpolated to the huge area. Interpolation results in a significant decrease in the index accuracy. As the $S H C$ has an acceptable correlation to VCI, calculated with satellite data (TERRAIMODIS) it is possible to use VCI instead of SHC. The optimal for septoria leaf blotch development interval of VCI calculated for late spring (May) of the current year is 0,1-0,3 (Malakhov et al., 2017). There are two obvious benefits from using VCI instead of $S H C$ : the fine spatial resolution of the data (up to 250 meters per pixel) and high temporal frequency of data, available online from Copernicus Global Land Service portal (https://land.copernicus.eu/global/products/vci) three times per month.

Septoria is known to winter in wheat residue, left in a field after harvesting. Field with vegetation residue on the ground has a high risk for the septoria leaf blotch development next year. However, the persistence of wheat residue is considered an important measure of snow retention and consequent increasing of soil water content in spring in arid and semi-arid regions. Among the mechanisms reportedly involved in disease establishment and year-to-year disease transmission, infection by pycnospores, splash-dispersed either from neighboring wheat debris or from senescent basal leaves, has also been considered as significant (Suffert et al., 2011). The presence of wheat residue may be calculated from high resolution satellite data, like Landsat or Sentinel-2, by various methods as the straw has quite a distinct spectral characteristic (Daughtry et al., 2010). There are several expressions to identify the presence of wheat residue at the open soil surface (McNairn, Protz, 1993; Qi et al., 2002; Peñuelas et al., 1994). Some indices refer to short-wave infrared bands of satellite imagery, which makes some limitations regarding the use of high-resolution satellite data, as many commercial sensors only encompass near-infrared wavelengths. For the current study, the simple and universal index of Xanthophyll Activity was applied (Table 1), which works with red and blue bands, available in every optical satellite sensor. To distinguish the presence of wheat residue, it is worth using either autumn snowless satellite imagery was taken after harvesting or snowless spring data taken before the start of agricultural activity. Figure 8 illustrates the result of wheat residue recognition for JSC "Novokubanskoye".

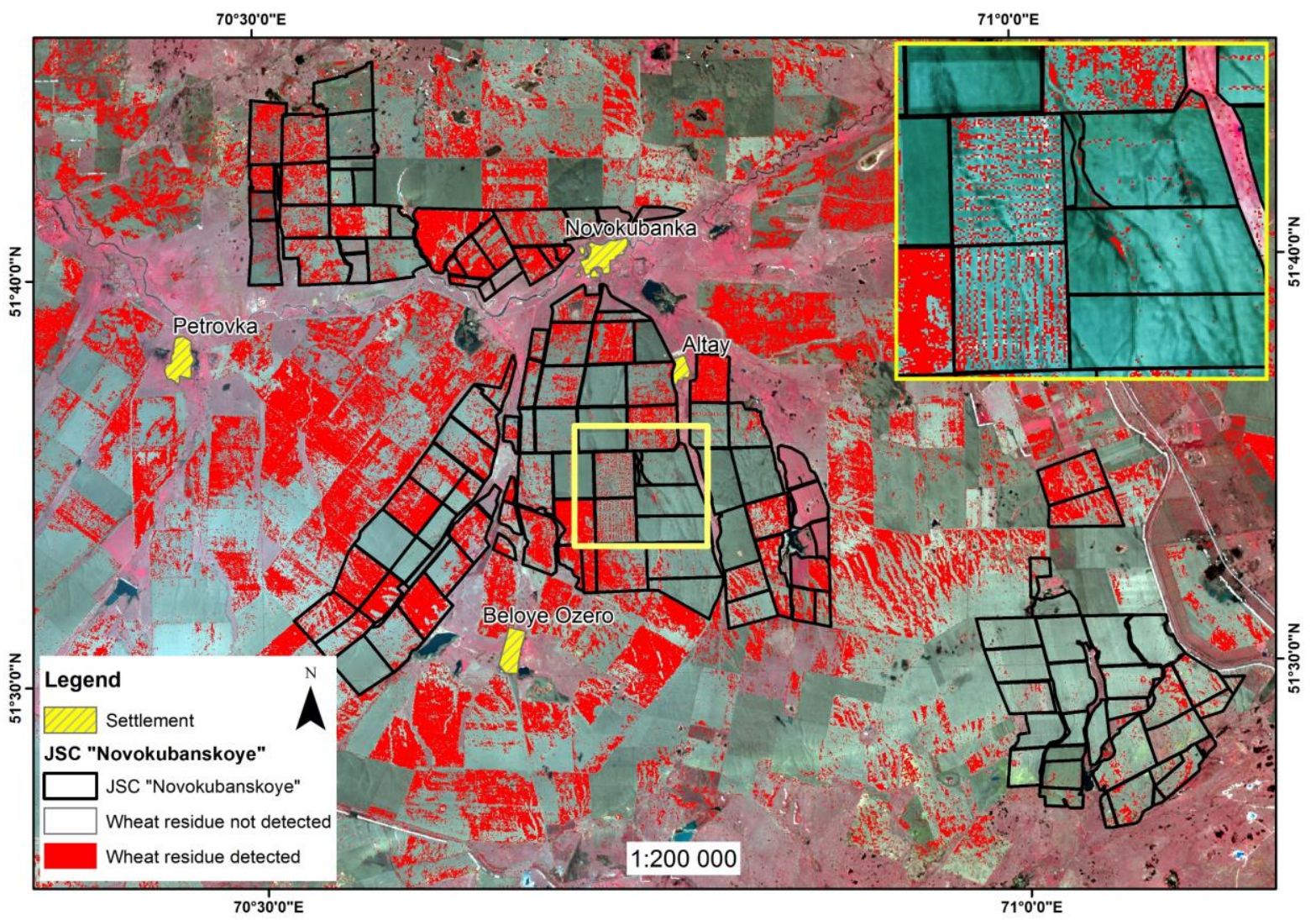

Figure 8. Wheat residue detected at JSC "Novokubanskoye" fields by XA Index. April, 2020. 
The prognosis map for the current year is the sum of all three components for every single field. The calculation of the prognostic map is being held formally from raster bands for each variable and the mask of crop rotation with ArcGIS functions. It is accepted for current prognostic maps to designate the septoria leaf blotch probability as follows:

a) high probability - all optimal ranges (from SDM, VCI, and wheat residue rasters) are presented within the certain field's border;

б) moderate probability - two of three variables overlap within the single field's border;

в) low risk - only one or none of three variables are presented within the field.

A prognostic map for the year 2020, as shown in Figure 9, demonstrates fields of different risks of septoria leaf blotch appearance.

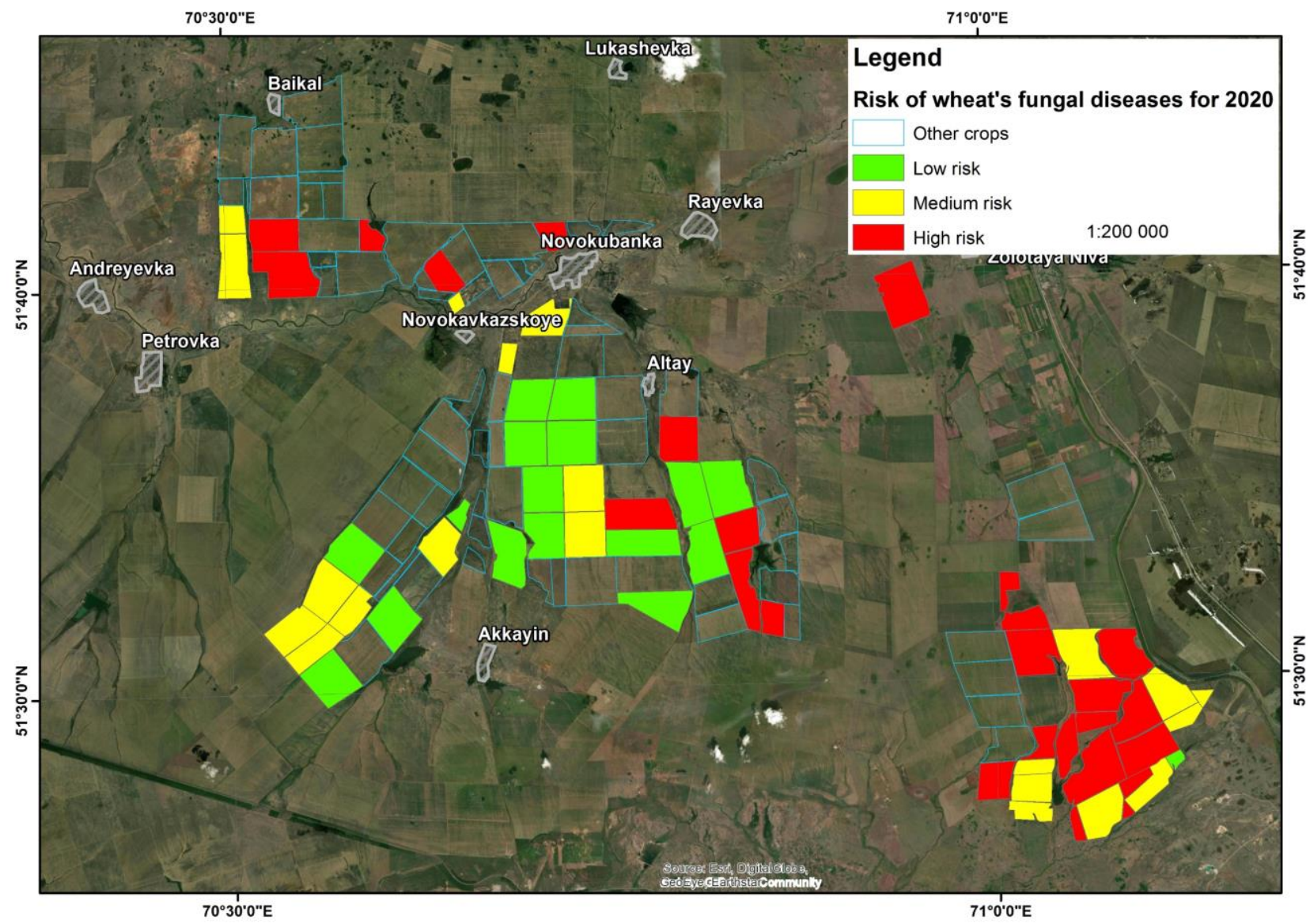

Figure 9. The map of septoria leaf blotch risk, JSC "Novokubanskoye", 2020. Red color - high risk, Yellow color - moderate risk, Green color - low risk, Transparent fields - non-wheat crops.

The prognostic map was verified in August 2020. The part of the JSC "Novokubanskoye" ("7th Department", shown at the southeast corner of Figure 9) was not treated against fungal diseases at all. These fields were sowed late, at the beginning of June, and, due to the absence of rainfall, crops appeared to grow very irregularly, leaving empty waste areas, where sprouts emerged much later or not grew out at all. JSC "Novokubanskoye" managers decided to leave this parcel "as is" without any treatment, so the " $7^{\text {th }}$ Department" represented an ideal case to verify the prognostic map. Verification was held in the second decade of 2020 August by field observation and registration of septoria leaf blotch cases. The septoria leaf blotch severity was estimated visually in each randomly selected control point accordingly to accepted classification (see above) as an 
averaged severity for all the plants in the field of operator's view (about 2 square meters). The general distribution of field-registered septoria leaf blotch severity fits well into the prognostic map (Figure 10).

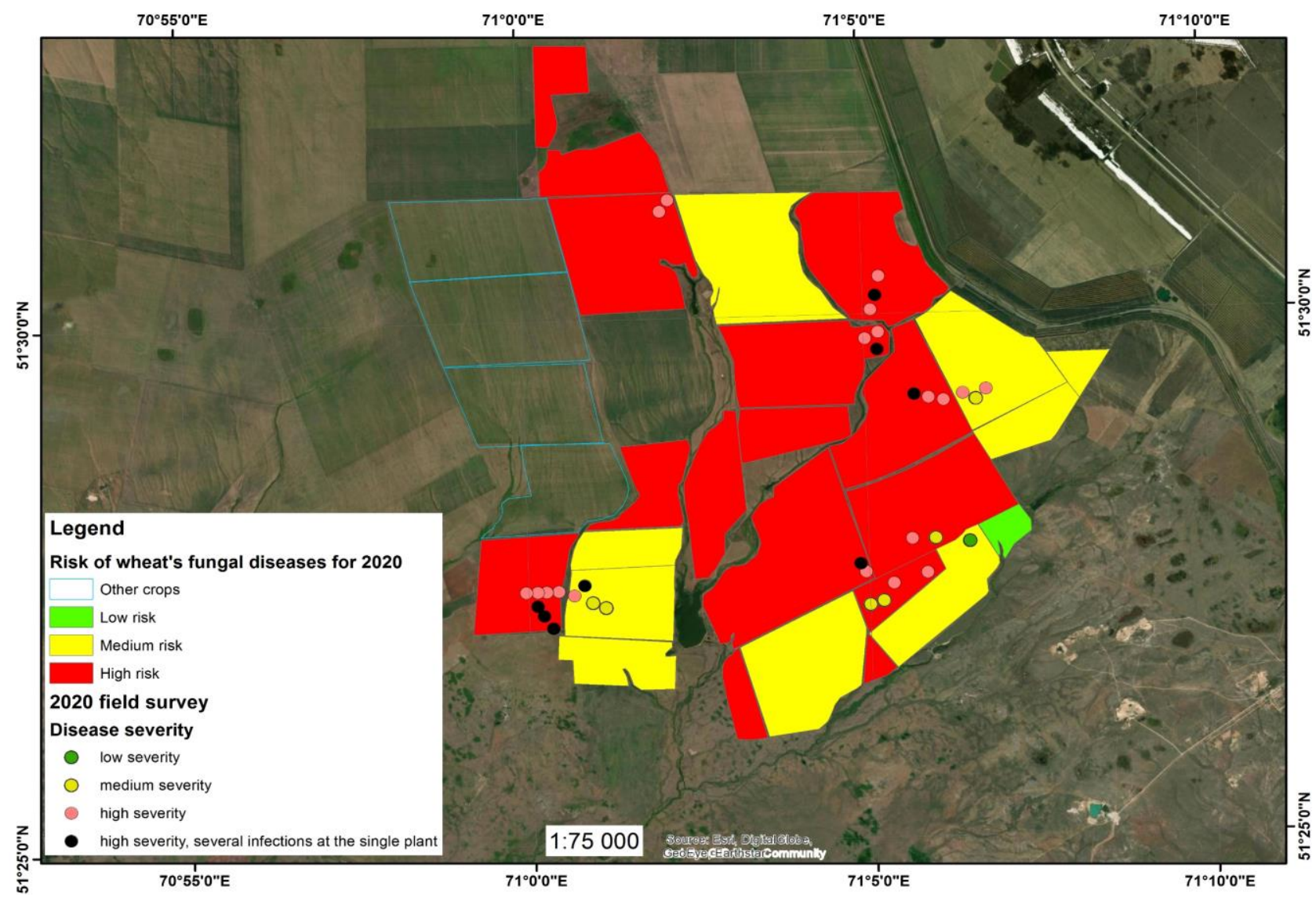

Figure 10. The distribution of ground-estimated septoria blotch severity upon the prognostic map, early August 2020.

The prognostic map is being prepared before the end of May, as it utilises VCI values of May, i.e. before the planting or during the planting (depending on the weather of a given year, the planting starts in the middle of May and continues during the first decade of June). Thus, the farmer might consider fields of increased attention long before the situation will get worse.

\section{Discussion}

The disease cycle of the Septoria parasite is very similar for all know species of Septoria. Infected crop residue is the most important source of primary inoculum, although infected seeds and alternative hosts may also be important in the epidemiology of septoria leaf blotch. A principal cause of the subsequent spread of disease is the predominantly vertical movement of pycnospores by rain splash (Shaw, Royle, 1993). The decreasing of the chlorophyll content is the most obvious symptom of most fungal diseases, including septoria leaf blotch and leaf rust. Symptoms induced by Septoria tritici appear successively on a leaf as chlorosis; irregular light green blotches with rectangular form, before evolving to brownish blotches called necrosis, thereafter leaves are covered with pycnidia. These rectangular blotches occupy large leaf areas; moreover, septoria leaf blotch (caused by Mycosphaerella graminicola) induces accelerated leaf senescence. Senescence development was also found strongly related to disease severity (El Wazziki et al., 2015). Symptoms of many fungal infections, being related to a decrease of the chlorophyll content, may appear very similar in terms of satellite spectral indices. Satellite sensors are sensitive to chlorophyll concertation in living plants, which makes the satellite data a reliable source of information of possible appearance and spread of the infection over the area. Ashourloo et al. (2014a) confirmed the disease symptoms have a high impact on the infected plant spectra. 
Assuming the simultaneous sowing, when the entire field is processed within the same day, one could expect the even and uniform development of crops. However, this ideal situation is usually disturbed by many factors making the crop condition uneven within the field. The presence of local tiny relief depressions may outline the area of water accumulation where the crops will appear healthier than in neighboring drier areas. Rains leading to infection of less mature plants will facilitate the multiplication of the pathogen on more advanced path (Parker et al., 1997). Additional factors as the presence of weeds, the appearance of pests or other infections, the uneven seeding, etc., provide further intermittence of $S L B S$ values within a field. The spots of crop's unevenness revealed by indices are the key areas to point the farmer's attention.

The $S L B S$-approach functions in the same way with spectral indices used to estimate the severity of wheat leaf rust (Ashourloo et al., 2014b), i.e., the index represented a linear regression equation, demonstrating a high correlation with septoria leaf blotch manifestations. To apply the $S L B S$, it is strictly necessary to have the crop rotation scheme, as $S L B S$ will provide false alarm at fields with non-wheat crops. Within wheat fields, SLBS reveals unevenness of the distribution of values, where relatively high values indicate the possible focus of septoria leaf blotch appearance. Farmer can effectively plan the use of fungicides, addressing the treatment to proper infection foci instead of the fungicide spray over all the wheat area. In the year 2019, the cost of treatment was about 2 USD per hectare, which means the total cost of the single fungicide treatment is 60000 USD if process the entire area of JSC "Novokubanskoye".

Additional indices (RETA, VSDI, vegetation indices) may provide more detailed information on the problem spots within a single field. Both earing and flowering stages are optimal to observe the uneven distribution of SLBS values, as fungicides have a high impact when the seed is still not formed and, thoroughly, is not affected with infection. Those parts of the wheat field, where the $S L B S$ values are significantly higher than the average value for the given field, must attract the immediate attention of the farmer and, most likely, will require fungicide injection as a focus of developing an infection.

Monitoring of crops assumes several approaches, focused on revealing the above-mentioned unevenness of crops. The information on crop condition provided to the farmer, consists of the following parameters: a) the dispersion of vegetation index values; $b$ ) the distribution of relative evapotranspiration values; c) relative water content in plants; d) the distribution of SLBS values.

The modeling of potential wheat disease development and disease severity is the subject of current studies (Chaloner et al.,2019; Beest et al., 2009; Savary et al., 2015). There is a number of issues associated with predictive disease models (Minchinton et al., 2008):

1. They predict sporulation or infection based on historical microclimatic data, which means that the response time to apply fungicides may be limited;

2. They can overestimate sporulation or infection events. If the disease is not present in the crop and there are no obvious sources of spores in the field or farming area, the microclimate data can still predict sporulation or infection events;

3. They may require the tolerance of very low levels of symptoms in the field, as it may not be economically viable to eradicate the disease from the crop completely.

An accurate forecast of damage level from septoria blotch mainly requires data on rain, rain splash, and the precise growing pattern of the crop (Shaw, Royle, 1993).

\section{Conclusions}

The early prognostic method described in this paper does not represent a true model and will not provide an exact prognosis of the septoria leaf blotch severity. The main purpose of this simple prognostic method is to point the farmer's attention at the fields with a high probability of septoria leaf blotch appearance, making the farmer free to select the mode of observation and countermeasure activity. The use of the SLBS-approach is limited when there is no detailed information on the planting dates and crop rotation. The SLBS may also 
provide false alarm at late crops if consider to neighboring early sowed fields. The high response of the index at late or uneven crops is physically based on the strong signal from open soil, which oversaturates chlorophyll's signal. However, the purpose of the $S L B S$-approach is the early identification of the unevenness within the single field, assuming that the sowing was undertaken simultaneously. The combination of monitoring and prognostic functions herein described provides a farmer with the information on the probability of disease appearance at every single field and with the information on the crop condition of each field during the vegetation season. From the stage of wheat flowering, the $S L B S$-approach provides adequate information of possible disease spread within each field. Farmer, provided with a variety of the information from SLBS, RETA, $V S D I$, and prognostic model, may precisely point his attention to the hot-spots long before the preventive countermeasures will become ineffective. The efficiency of the proposed approach is defined by reducing fungicide treatment cost, as the farmer may address the application of fungicides exactly to the spot of disease appearance instead of total treatment of all fields. Apart from the reduced amount of chemical agents, the welltimed treatment could reduce the yield loss up to 3-4 c/ha or up to $30 \%$ of the average yield in the agricultural zone of Central Kazakhstan. The project of crop monitoring at the fields of JSC 'Novokubanskoye' is continuous, and data of 2021 and future years will be used to further enhance proposed algorithms.

\section{Acknowledgment}

The administration of JSC "Novokubanskoye" and personally the agronomist N. V. Tsiunel granted us valuable information on crop rotation. N. V. Tsiunel provided comprehensive assistance and information during the field seasons of 2019-2020. Rashid Iskakov (JSC "NCSRT") and Zharas Ainakulov (JSC "NCSRT") helped to organize and held field observations and instrumental measurements. Two anonymous reviewers have our gratitude for their valuable comments helping to improve the manuscript further. This work was carried out under the auspices of the Republican budget program 008 "Applied Scientific Research in the Field of Space Activities".

\section{References}

Ashourloo, D., Mobasheri, M. R., Huete, A. (2014a). Evaluating the effect of different wheat rust disease symptoms on vegetation indices using hyperspectral measurements. Remote Sens. 6, 5107-5123. doi:10.3390/rs6065107.

Ashourloo, D., Mobasheri, M. R., Huete, A. (2014b). Developing two spectral disease indices for detection of wheat leaf rust (Puccinia triticina). Remote Sens. 6, 4723-4740. doi:10.3390/rs6064723.

Babkenova, S. A., Babkenov, A. T., Pakholkova, E. V., Kanafin, B. K. (2020). Pathogenic complexity of septoria spot disease of wheat in northern Kazakhstan. Plant Science Today. 7(4), 601-606. https://doi.org/10.14719/pst.2020.7.4.798.

Beest, D. E., Shaw, M. W., Pietravalle, S., van den Bosch, F. (2009). A predictive model for early-warning of Septoria leaf blotch on winter wheat. Eur J Plant Pathol. 124, 413-425 doi:10.1007/s10658-009-9428-0.

Chaloner, T.M., Fones, H.N., Varma, V., Bebber, D.P., Gurr, S.J. (2019). A new mechanistic model of weather-dependent Septoria tritici blotch disease risk. Phil. Trans. R. Soc. B, 374, 20180266. http://dx.doi.org/10.1098/rstb.2018.0266.

Cooke, B.M., Jones, G.D., Kaye, B. (2006). The epidemiology of plant diseases. 2nd Edition, 43-80.

Daughtry, C. S.T., Serbin, G., Reeves, J. B., Doraiswamy, P. C., Hunt, E. R. (2010). Spectral reflectance of wheat residue during decomposition and remotely sensed estimates of residue cover. Remote Sens. 2, 416-431; doi:10.3390/rs2020416.

Diseases of crops. (V.F.Peresypkin, Ed.). (1989). Vol.1: Diseases of grain and leguminous crops. Kiev. 231 p.

El Wazziki, H., El Yousfi, B., Serghat, S. (2015). Grain yield prediction from brown rust (Puccinia triticina) and leaf blotch (Septoria tritici) severity on wheat flag leaves. Revue Marocaine de Protection des Plantes, 7, 51-65.

Gao, B. (1995). Normalized difference water index for remote sensing of vegetation liquid water from space. Proceedings of SPIE 2480., 225-236.

Gitelson, A. A., Stark, R., Grits, U., Rundquist, D., Kaufman, Y., Derry, D. (2002). Vegetation and soil lines in visible spectral space: a concept and technique for remote estimation of vegetation fraction. International Journal of Remote Sensing, 23, 2537-2562.

Hess, D. E., Shaner, G. (1987). Effect of moisture on Septoria tritici blotch development on wheat in the field. Phytopathology, 77(2), 220-226 
Huete, A., Didan, K., Miura, T., Rodriguez, E.P., Gao, X., Ferreira, L.G. (2002). Overview of the radiometric and biophysical performance of the MODIS vegetation indices. Remote Sensing of Environment, 83, 195-213.

Jackson, T. J., Chen, D., Cosh, M., Li, F., Anderson, M., Walthall, C., Doriaswamy, P., Hunt, E. R. (2004). Vegetation water content mapping using Landsat data derived normalized difference water index for corn and soybeans. Remote Sensing of Environment, 92, 475-482.

El Jarroudi, M., Kouadio, A. L., Mackels, C., Tychon, B., Delfosse, P., Bock, C. H. (2015). A comparison between visual estimates and image analysis measurements to determine septoria leaf blotch severity in winter wheat. Plant Pathology, 64, 355364. doi: 10.1111/ppa.12252

Karjalainen, R., Karjalainen, S. (1990). Yield reduction of spring wheat in relation to disease development caused by Septoria nodorum. Journal Of Agricultural Science In Finland, 62, 255-263.

Kaufman, Y., Tanre, D. (1992). Atmospherically resistant vegetation index (ARVI) for EOS-MODIS. IEEE Transactions on Geoscience and Remote Sensing, 2, 261-270.

Kogan, F.N. (2001). Operational space technology for global vegetation assessment. Bull. Amer. Meteor. Soc., 82(9), 1949-1964.

Kottek, M., Grieser, J., Beck, C., Rudolf, B., \& Rubel, F. (2006). World Map of the Köppen-Geiger climate classification updated. Meteorologische Zeitschrift, 15(3), 259-263. https://doi.org/10.1127/0941-2948/2006/0130

Koyshibayev, M. (2002). Diseases of grain crops. Almaty. 367 p.

Minchinton, E., Galea, V., Auer, D., Harapas, D., Thomson, F., Vassiliadis, S., Trapnell, L. N., Vujovic, S. (2008). Validation of a disease forecasting model to manage late blight (Septoria) in celery. HAL Final report VG06047. State of Victoria, Department of Primary Industries. 68 p.

McNairn, H.; Protz, R. (1993). Mapping corn residue cover on agricultural fields in Oxford County, Ontario, using Thematic Mapper. Can. J. Remote Sens., 19, 152-159.

Melkumov, G.M., Brazhnikova, I.A. (2018). Taxonomy and ecological peculiarities of Septoria Sacc. species in Voronezh Region. Proceedings of Volga State University. Series: Chemistry, Biology, Pharmacy. 2, 185-190.

Malakhov, D.V., Tsychuyeva, N.Yu., Vitkovskaya, I.S. (2017). Modelling the ecological niche of wheat septoriosis using remote sensing data. Current Problems In Remote Sensing Of The Earth From Space. 14(1), 113-124. doi:10.21046/2070-74012017-14-1-113-124

Parker, S.R., Shaw, M.W., Royle, D.J. (1997). Measurements of spatial patterns of disease in winter crops and the implications for sampling. Plant Pathology, 46,470-480.

Peñuelas, J., Gamon, J.A., Fredeen, A.L., Merino, J., Field, C.B. (1994). Reflectance indices associated with physiological changes in nitrogen- and water-limited sunflower leaves. Remote Sensing of Environment, 48, 135-146.

Peresypkin, V.F. 1(969). Agricultural phytopathology. "Kolos", 479 p.

Qi, J.; Marsett, R.; Heilman, P.; Biedenbender, S.; Biedenbender, S.; Moran, M.S.; Goodrich, D.C.; Weltz, M. (2002). RANGES improves satellite-based information and land cover assessments in Southwest United States. EOS Trans. Am. Geophys. Union, 83, 601-606.

Roujean, J.L., Breon, F.M. (1995). Estimating PAR absorbed by vegetation from bidirectional reflectance measurements. Remote Sens. Environ., 51, 375-384.

Rouse, J. W. Jr., Haas, R. H., Schell, J. A. and Deering, D. W. (1973). Monitoring vegetation systems in s with ERTS. In Third ERTS Symposium, NASA SP-351, U.S. Government Printing Office, Washington, DC, 1, 309-317.

Savary, S., Stetkiewicz, S., Brun, F., Willocquet, L. (2015). Modelling and mapping potential epidemics of wheat diseases-examples on leaf rust and Septoria tritici blotch using EPIWHEAT. Eur J Plant Pathol., doi 10.1007/s10658-015-0650-7

Selyaninov, G.T. (1937). Methodics of agricultural characteristics of climate. World Agroclimatic Hand Book. Leningrad-Moscow. $412 \mathrm{p}$.

Shaw, M.W., Royle, D.J. (1989). Estimation and validation of a function describing the rate of yield loss in winter wheat due to infection by Mycosphaerella graminicola. Annals of Applied Biology, 115, 425-442.

Shaw, M.W., Royle, D.J. (1993). Factors determining the severity of epidemics of Mycosphaerella graminicola (Septoria tritici) on winter wheat in the UK. Plant Pathology, 42, 882-899.

Suffert, F., Galet, N., Sache, I. (2011). Effect if wheat debris as source of primary inoculum on the early stages of Septoria leaf blotch epidemics. 8. International symposium on Mycosphaerella and Stagonospora diseases of cereals, Sep 2011, Mexico, Mexico, 80. 〈hal-01000709〉

Tadesse, Y., Chala, A., Kassa, B. (2020). Yield loss due to Septoria tritici Blotch (Septoria Tritici) of bread wheat (Triticum aestivum L.) in the Central Highlands of Ethiopia. Journal of Biology, Agriculture and Healthcare, doi 10(10):1-7. DOI: 10.7176/JBAH/10-10-01

Toropova, E.Yu., Kazakova, O.A., Selyuk, M.P. (2016). Monitoring of Septoria blight on spring wheat in the forest-steppe of Western Siberia. Dostizheniya nauki i tekhniki APK., 30(12), 33-35.

Verreet, J.A., Klink, H., Hoffmann, G.M. (2000). Regional monitoring for disease prediction and optimization of plant protection measures: the IPM Wheat Model. Plant Disease, 84(8), 816-826. 
Yang, Z., Willis, P., Mueller, R. (2008). Impact of band-ratio enhanced AWIFS image to crop classification accuracy. Proceedings of the Pecora 17 Remote Sensing Symposium. Denver, CO.

Wang, Y., Zia, S., Owusu-Adu, S., Gerhards, R., Müller, J. (2014). Early detection of fungal diseases in winter wheat by multioptical sensors. APCBEE Procedia, 8, $199-203$.

Wang, F.-M., Huang, J.-F., Tang, Y.-L., Wang, X.-Z. (2007). New vegetation index and its application in estimating leaf area index of rice. Rice Science, 14(3), 195-203.

Zhang, N., Hong, Y., Qina, Q., Liu, L. (2013). VSDI: a visible and shortwave infrared drought index for monitoring soil and vegetation moisture based on optical remote sensing. International Journal of Remote Sensing, 34(13), 4585-4609. 